\title{
Volatility and Entrainment of Feed Components and Product Glass Characteristics During Pilot-Scale Vitrification of Simulated Hanford Site Low-Level Waste
}

G. A. Whyatt

Pacific Northwest National Laboratory

J. W. Shade

G. E. Stegen

Westinghouse Hanford Company

Date Published

April 1996

To Be Presented at

Spectrum '96

Seattle, Washington

August 18-23, 1996

Prepared for the U.S. Department of Energy

Assistant Secretary for Environmental Restoration and Waste Management

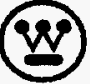

Management and Operations Contractor for the

U.S. Department of Energy under Contract DE-AC06-87RL10930

Copyright License By acceptanco of this article, the publisher and/or recipient acknowledges the

U.S. Government's right to retain a nonexdusive, royaity-freo licenso in and to ony copyright covering thia paper. 
THIS PAGE INTENTIONALLY

LEFT BLANK. 
LEGAL DISCLAIMER

This report was prepared as an account of work sponsored by an agency of the United States Government. Neither the United States Government nor any agency thereof, nor any of their employees, nor any of their contractors, subcontractors or their employees, makes any warranty, express or implied, or assumes any legal liability or responsibility for the accuracy, completeness, of any third party's use or the results of such use of any information, epparatus, product, or process disclosed, or represents that its use would not infringe privately owned rights. Reforence herein to any specific commercial product, process, or service by trade name, tredemark, manufactures, of otherwise, does not necessarily constitute or imply its endorsement, recommendation, or fevoring by the United States Government or any sgency thereof or its contractors or subcontractors. The views and opinions of authors expressed herein do not necessarily state or reflect those of the United States Government or any agency thereof.

This report has been reproduced from the best aveilable copy.

Printed in the Unitod States of Amarice

DISCLM-2.CHP (1-91) 
THIS PAGE INTENTIONALLY

LEFT BLANK 


\section{INFORMATION RELEASE REQUEST - (Long Form)}

(GRAY SHADED AREAS NOT TO BE FILLED IN BY INITIATOR)

1. COMPLETE THIS SECTION FOR ALL DOCUMENTS

\begin{tabular}{|c|}
\hline \multicolumn{2}{|c|}{ A. Information Category } \\
\hline Speech or Presentation \\
$\square$ Full Paper \\
$\square$ Summary \\
$\square$ Abstract \\
$\square$ Multimedia Presentation \\
$\square$ Software \\
$\square$ Visual Ald \\
$\square$ Othes
\end{tabular}

B. Document ID Number (include rev., vol., etc.)

WHC-SA-3093-FP

C. Llet attachmente (1.e., copyright permiseion, copyright transfer)

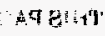

D. Document Title

Volatility and Entrainment of Feed Components and Product G1ass

Characteristics During Pilot-Scale Vitrification of Simulated Hanford Site

Low-Leve1 Waste

E. WHC Project or Program

TWRS LLW

Program

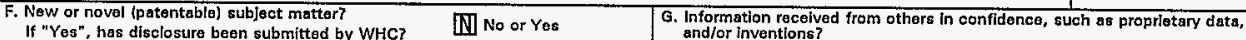 \\ $\square$ No or Yes if "Yes", Disclosure No(s): \\ [N] No or Yes \\ If "Yes", contact WHC Generai Counsel.}

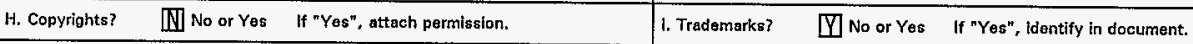
2. COMPLETE THIS SECTION FOR ALL DOCUMENTS REQUIRING SUBMISSION TO OSTI

\begin{tabular}{|l|l|l}
\hline A. Unclassified Category & UC - Budget \& Reporting Code & B\&R - EW3130010
\end{tabular}

3. COMPLETE THIS SECTION ONLY FOR A JOURNAL SUBMISSION

A. Title of Journai

4. COMPLETE THIS SECTION ONLY FOR A SPEECH OR PRESENTATION

\begin{tabular}{|l|l|l|}
\hline $\begin{array}{l}\text { A. Title for Conference or Meeting } \\
\text { Spectrum '96 }\end{array}$ & $\begin{array}{c}\text { B. Group or Society Sponsoring } \\
\text { American Nuclear Socjety }\end{array}$ \\
\hline $\begin{array}{l}\text { C. Dateisl of Conference } \\
\text { or Meeting }\end{array}$ & D. City/State & $\begin{array}{l}\text { E. Will material be published in proceedings? } \\
\text { Will material be handed out? }\end{array}$ \\
Aug. $18-23,1996$ & Seattle, Washington & W] No or Yes
\end{tabular}

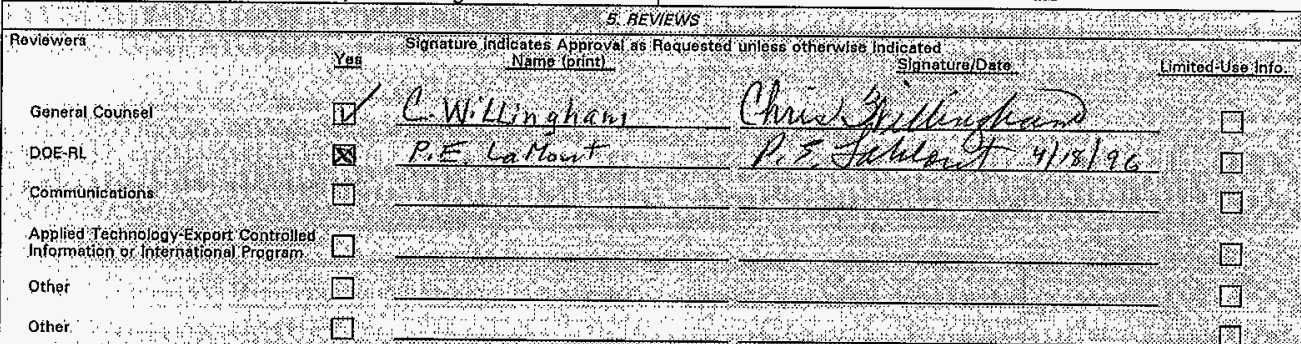

6. Applled Technology Material Referenced

$[\mathrm{X}]$ No $\square$ Yos

7. Release Level

$[X]$ Public $\square$ Limited Distribution

8. Author/Requestor

$\frac{\text { John W. Shade }}{\text { (Print and Sian) }}$. N. Shade

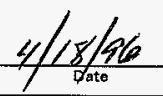

9. Responsible Manager

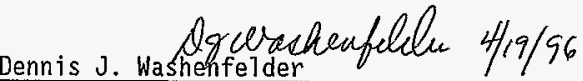
(Print and Sign)

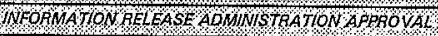

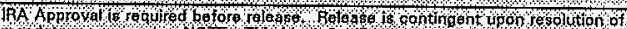

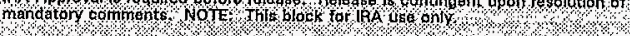

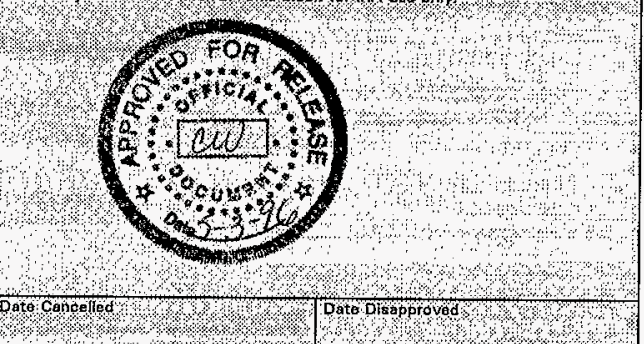

A-6001-401 (07/94) 

WHC-SA-3093-FP

Dooument ID Number

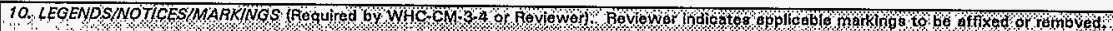

Aftix Bomive. Initials

Appliso Teotinoto

Avaliabitity ost

Avallability $\mathrm{ESSC}$

Avallability $\mathrm{NTS}$

Bustiése-Sensitive toformation

Computer Software Notiça

Copyotoht License Notice

Expont controlled Intomation

Ledalipisctomor

fimitad orstopre

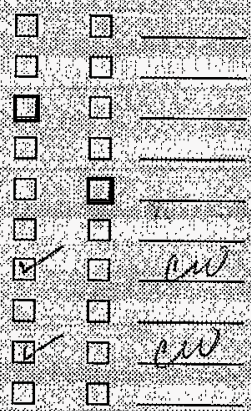

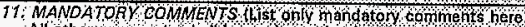
All other comments thit bo modon the dociment and tewurned to the authori

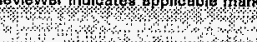

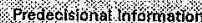

Probranmatur Notice

Proprietan' laformation

P

Thegis o is sertaton

Trademark Dtrofalmat

other:

Affix Renove tnitials

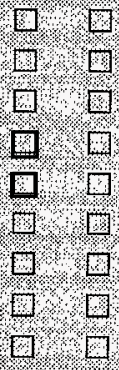

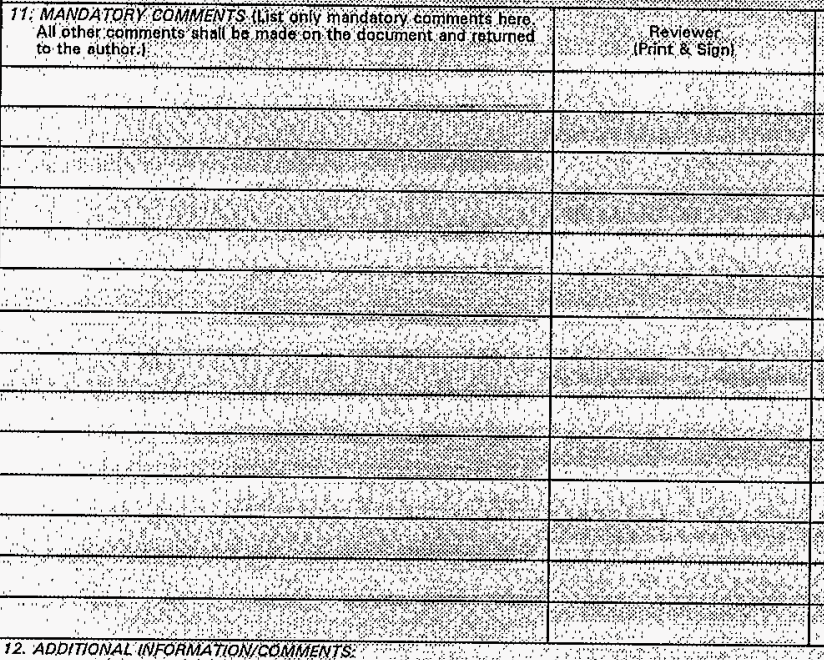

\begin{tabular}{|c|c|c|}
\hline ote & $\begin{array}{l}\text { Resolved by Author/Requestor } \\
\text { (Frint \& Sign) }\end{array}$ & Date \\
\hline 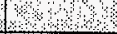 & & \\
\hline 1 & & \\
\hline & & \\
\hline 8 & & \\
\hline 3 & & \\
\hline 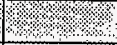 & & \\
\hline m, & & \\
\hline $1 \% 1 \%$ & & \\
\hline & & \\
\hline 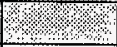 & & \\
\hline ४ & & \\
\hline$\% \%, \%$ & & \\
\hline & & \\
\hline 3 & & \\
\hline
\end{tabular}

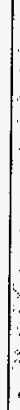


THIS PAGE INTENTIONALLY

LEFT BL.ANK 


\section{VOLATIITY AND ENTRAINMENT OF FEED COMPONENTS AND PRODUCT GLASS CHARACTERISTICS DURING PILOT-SCALE VITRIFICATION OF SMULATED HANFORD SITE LOW-LEVEL WASTE}

Greg A. Whyatt

Pacific Northwest National Laboratory

P.O. Box 999

Richland, Washington 99352

(509)376-0011
John W. Shade

Westinghouse Hanford Co.

P.O. Box 1970

Richland, Washington 99352

(509)373-5922
Gary E. Stegen

Westinghouse Hanford Co.

P.O. Box 1970

Richland, Washington 99352

(509)376-5548

\section{ABSTRACT}

Commercially available melter technologies were tested for application to vitrification of Hanford Site low-level waste (LLW). Testing was conducted at vendor facilities using a nonradioactive $L L W$ simulant. Technologies tested included four Joule-heated melter types, a carbon electrode melter, a cyclone combustion melter, and a plasma torch-fired melter. A variety of samples were collected during the vendor tests and analyzed to provide data to support evaluation of the technologies. This paper describes the evaluation of melter feed component volatility and entrainment losses and product glass samples produced during the vendor tests. All vendors produced glasses that met minimum leach criteria established for the test glass formulations, although in many cases the waste oxide loading was less than intended. Entrainment was much lower in Joule-heated systems than in the combustion or plasma torch-fired systems. Volatility of alkali metals, halogens, B, $\mathrm{Mo}$, and $\mathrm{P}$ were severe for non-Joule-heated systems. While losses of sulfur were significant for all systems, the volatility of other components was greatly reduced for some configurations of Joule-heated melters. Data on approaches to reduce $\mathrm{NO}_{x}$ generation, resulting from high nitrate and nitrite content in the double-shell slurry feed, are also presented.

\section{INTRODUCTION}

Vitrification was specified in the 1994 revision of the TriParty Agreement ${ }^{1}$ as the treatment method for the low-level waste $(L L W)$ streams derived from retrieval and pretreatment of both double-shell tank (DST) and single-shell tank (SST) wastes at the Hanford Site. A multiphase program was initiated with commercial melter technology vendors in 1994 to test and evaluate promising melter technologies using nonradioactive $L L W$ simulants. Phase 1 testing with melter vendors was described in the previous paper. ${ }^{2}$ Documents containing a summary of Phase 1 testing activities and an evaluation of volatility, entrainment, and $\mathrm{NO}_{x}$ emissions were prepared. $^{3,4}$ Six vendors successfully completed Phase 1 testing. These vendors and their respective vitrification technologies are as follows.
Babcock \& Wilcox (B\&W), Alliance Research Center, Alliance, Ohio--Gas-fired cyclone combustion metter, slurry feed

Westinghouse Science and Technology Center (WSTC), Pittsburgh, Pennsyivania--Plasma torch-fired cupola furnace, slurry feed

U.S. Bureay of Mines (USBM), Albany Research Center, Albany, Oregon--Carbon electrode melter, prereacted dry feed

Vectra Technologies, Inc. (Vectra), Richland, Washington--High-temperature Joule-heated melter, topentry molybdenum electrodes, slurry feed

GTS Duratek Inc. (Duratek), Columbia, Maryland-Low-temperature Joule-heated melter, Inconel ${ }^{2}$ electrodes, slurry feed

Envitco. Inc. (Envitco), Toledo, Ohio--High-temperature Joule-heated meiter, molybdenum electrodes, wetted pelletized feed.

Samples were taken during testing by each vendor to address issues defined in the Statement of Work. ${ }^{5}$ Analyses of these samples were performed by contracted independent and government laboratories. ${ }^{2}$ Results from analyses were sent to Westinghouse Hanford Company (WHC) for review, distribution, and integration into an LLW melter testing database. ${ }^{6}$ In addition, each vendor contracted with a qualified air quality laboratory to perform specific offgas emissions measurements using standard U.S. Environmental Protection Agency (EPA) methods. These measurements included isokinetic sampling by Method 5 and/or Method 29 for multiple metals, Method 26A for determination of hydrogen halides and halogens, and continuous emissions monitoring for $\mathrm{NO}_{x}, \mathrm{CO}_{x}$ and $\mathrm{SO}_{2}$. The air quality laboratory emissions

\footnotetext{
2Inconel is a trademark of Inco Alloys, Inc.
} 
measurement data for each test were reported in each vendor's Phase 1 test report. $7,8,9,10,11,12$

This paper provides information on glass product characteristics and reports the results of an analysis of the selective (assumed to be volatization) and non-selective (assumed to be entrainment) losses of feed components to the offigas system. In addition, extimates are provided on the extent to which nitrate and nitrite in the feed are converted to $\mathrm{NO}_{\mathrm{x}}$ in the offgas. Information concerning the loss of feed components to the offigas system can be used as input to the offgas system design and to assess the practicality of recycling offgas emissions to the melter feed. The information also provides insight into likely compositions of secondary wastes resulting from offgas treatment.

\section{GLASS PRODUCT CHARACTERISTICS}

Two requirements were placed on the product glass in the Statement of Work ${ }^{5}$ First, the glass should have a waste loading (weight percent of glass oxides derived from the double-shell slurry feed [DSSF] simulant) of approximately $25 \%$. Secondly, the glass formulation should be reasonably durable with an Na normalized leach rate of $1 \mathrm{~g} / \mathrm{m}^{2} /$ day or less measured by the product consistency test (PCT) Method $\mathrm{A}^{13}$ Durability requirements for the LLW glass had not yet been established and the $1 \mathrm{~g} / \mathrm{m}^{2} /$ day PCT durability requirement was selected as a readily achievable durability approximately equivalent to that of the Savannah River "environmental assessment glass" used as a benchmark for high-level waste (HLW) glass durability. ${ }^{14}$

It was the intent of the Phase 1 melter tests for each vendor to demonstrate its ability to produce a homogeneous glass of consistent composition meeting these requirements using the DSSF simulant. The product was expected to be fully reacted and have a consistent composition with a minimum of inhomogeneities such as cords, stones, devitrification, and/or other inclusions. Complete refining to remove all seeds (small bubbles) was not required.

Vendors were responsible for selecting their glass formulations and had the option of using one of five glass formulations developed for Phase 1 testing by Pacific Northwest National Laboratory (PNNL), or of developing their own glass formulation. Envitco, B\&W, and USBM selected PNNL glass formulations while Duratek, WSTC, and Vectra elected to develop their own glass formulations. The DSSF simulant was provided to the vendors with a target $\mathrm{Na}$ concentration of $10 \mathrm{M}$. The target DSSF concentration and oxide composition was used by most vendors for the purpose of glass formulation and feed batch calculations for DSSF and glass formers.
The major oxide compositions of the simulated DSSF waste are provided in Table 1 along with the vendor target glass compositions and average compositions measured on Phase 1 testing product glass samples. $\mathrm{Na}_{2} \mathrm{O}$ accounts for $75.22 \mathrm{wt} \%$ of the waste oxides in the simulant and is not present in glass formers for any of the vendors except as impurities. Therefore, the target $25 \mathrm{wt} \%$ waste oxide loading requirement is equivalent to a target $\mathrm{Na}_{2} \mathrm{O}$ content of $18.8 \%$. The PNNL glasses and the Vectra glass formulation contain 20 wt $\% \mathrm{Na}_{2} \mathrm{O}$ which corresponds to a $26.6 \mathrm{wt} \%$ waste oxide loading. The major oxides of the planned glass formulations for each vendor are also shown in Table 1 along with the measured values from samples of the glass actually produced during testing. The reported measured glass values are averages of between 4 and 12 individual results from samples selected to match samples used in volatility calculations.

Some vendors did not meet the waste loading requirements. Low waste loadings in glasses produced during the Envitco and Duratek tests appear primarily to be the result of assuming the target $10 \mathrm{M} \mathrm{Na}$ concentration for the Lot 1 DSSF simulant used, which now appears to actually have been about $9.0 \pm 0.5 \mathrm{M} \mathrm{Na}$. Envitco used entirely Lot 1 simulant while Duratek used a mixture of Lots 1 and 2 simulant. Assuming $10 \mathrm{M} \mathrm{Na}$ concentration for the Lot 1 simulant was also likely a contributing factor in the below-target waste loadings achieved in the USBM and B\&W tests. As will be discussed later, volatility contributed to a shortage of alkali metals in the glass for some vendors. Simulant analyses were somewhat uncertain. All simulants contained settled solids which required resuspension before sampling and may have contributed to analytical errors. Several analyses were made on the Lot 1 simulant with results ranging from about $8 \mathrm{M}$ to $10 \mathrm{M}$ $\mathrm{Na}$. Fewer analyses were performed on Lot 2 with more consistent results indicating approximately $10.5 \mathrm{M} \mathrm{Na}$ concentration.

Additional information is provided in the final four rows of Table 1. The target viscosity data and PCT values were measured by PNNL on crucible melts batched from dry oxide and carbonate materiais. Acceptable PCT results $<1 \mathrm{~g} / \mathrm{m}^{2} /$ day normalized $\mathrm{Na}$ release were the basis for approval of vendorformulated glasses before conducting Phase 1 testing. The melting temperature at 100 poise viscosity was determined from an Arrhenius fit to the viscosity versus temperature data measured on the laboratory crucible melts. The "measured" values for $\mathrm{PCT}$ and $\mathrm{Fe}^{2+} / \mathrm{Fe}$ total are determined from sampies of glass from the vendor melter tests.

All vendors were able to produce glass significantly more durable than the $<1 \mathrm{~g} / \mathrm{m}^{2} /$ day normalized $\mathrm{Na}$ release PCT requirement for Phase 1 testing. Selected results for individual vendors are as follows. 


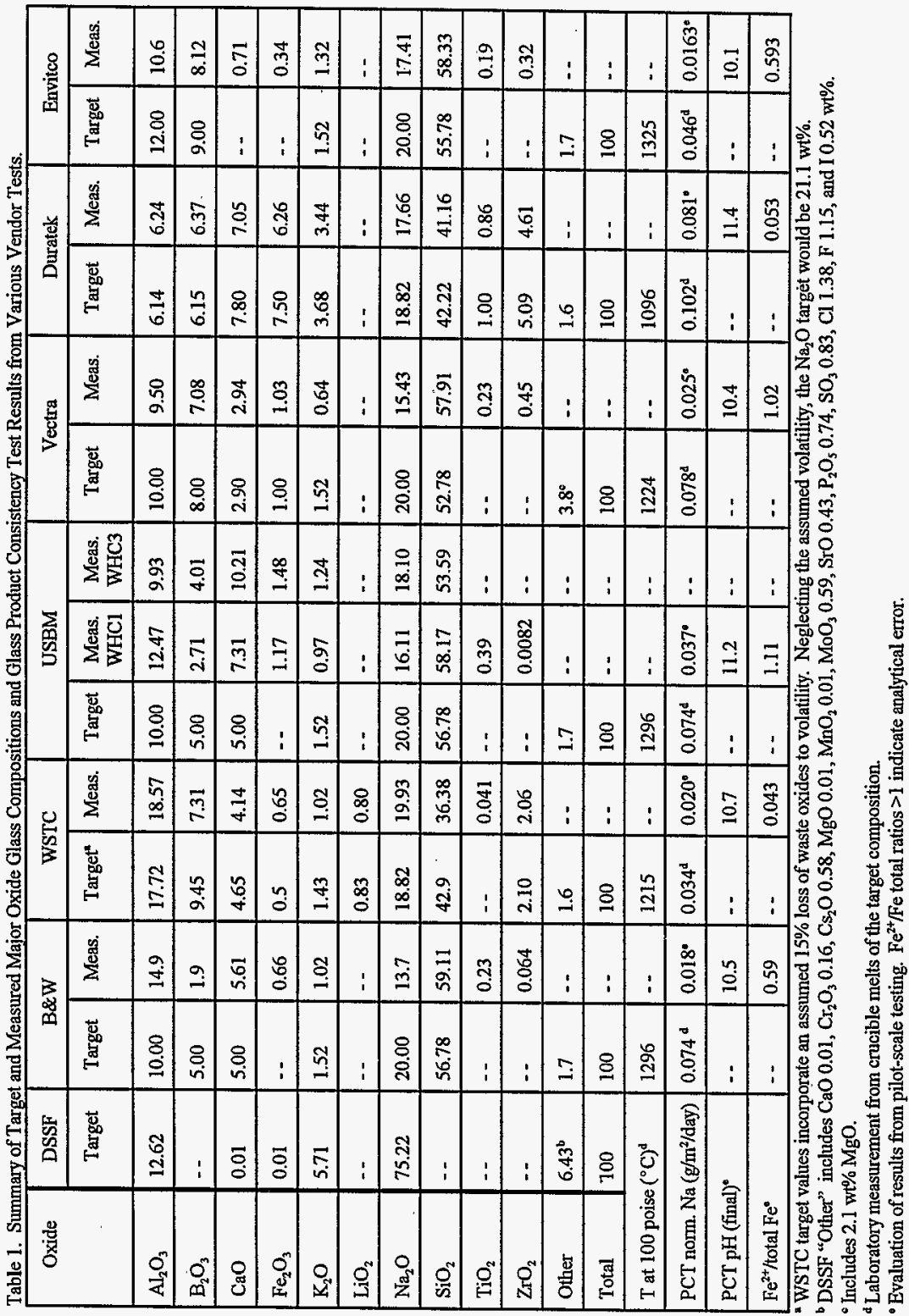




\section{A. B\&W Glass Product}

The glass samples were moderately reduced with $\mathrm{Fe}^{+2} / \mathrm{Fe}$ values ranging from 0.468 to 0.62 (seven analyses) suggesting that combustion conditions were slightly reducing. The PCT $\mathrm{Na}$ release values were significantly lower than the target glass value, which is consistent with the lower $\mathrm{Na}_{2} \mathrm{O}$, and higher $\mathrm{Al}_{2} \mathrm{O}_{3}$ and $\mathrm{SiO}_{2}$, compositions for the test glass samples.

The $B \& W$ glass was very inhomogeneous and incompletely reacted with inclusions ranging from 1 to $10 \mathrm{vol} \%$. The inclusions primarily consisted of unreacted $\mathrm{SiO}_{2}$ grains, and refractory components such as chromite, zircon, aluminous refractory grains, and spinels. The product contained heavy cords which were enriched in $\mathrm{Fe}$ and $\mathrm{Zr}$ and depleted in $\mathrm{Si}, \mathrm{Ca}$, and $\mathrm{Al}$. In addition, the $\mathrm{B} \& \mathrm{~W}$ product exhibited considerable foam regions and bubbles. $\mathrm{X}$-ray diffraction patterns showed considerable crystallinity. The $\mathrm{B} \& \mathrm{~W}$ melter configuration did not include a glass-refining reservoir, and residence time in the meiter at temperature was short (estimated at about 20 minutes). Melter design modification to include a refining reservoir and longer residence times, and the use of a more durable refractory material for lining the cyclone, would likely result in much improved glass product homogeneity and uniformity.

\section{B. WSTC Glass Product}

There was considerable uncertainty concerning actual melter feed compositions and mass balances during the WSTC testing. A pre-manufactured frit was separately metered and blended with the simulant just before injection as a slurry into the plasma melter tuyere. Simulant and frit feed rates were initially selected based on a $28 \%$ target waste oxide loading $\left(21.1 \% \mathrm{Na}_{2} \mathrm{O}\right)$ to adjust for an assumed $15 \%$ waste oxide volatility. Analyses of periodic slurry samples (mixed simulant and fiit) from the melter feed line indicate that the frit feed rate decreased relative to the simulant feed rate as the test progressed causing the melter feed waste loading to increase during the test.

The WSTC glass samples, along with those from the Duratek test, were the most oxidized glasses in terms of $\mathrm{Fe}^{+2} / \mathrm{Fe}$ ratio produced during the Phase 1 melter tests. The PCT Na releases ranged from 0.013 to $0.050 \mathrm{~g} / \mathrm{m}^{2} /$ day (five samples) compared to $0.034 \mathrm{~g} / \mathrm{m}^{2} /$ day measured on the qualification target glass composition.

Inclusions in the WSTC glass samples were generally $<1 \mathrm{vol} \%$ of the glass. They consisted of traces of $\mathrm{Fe}-\mathrm{Cr}$ opaques and feldspathic stones. Other inclusions were zircon grains and alumina refractory stones. Some devitrification was observed and was dominantly alkali aluminosilicate, which was not too surprising considering the high alumina content of the target composition. Cords were numerous, heavy, and multi-lamellar. Cords were enriched in $\mathrm{Al}, \mathrm{Zr}, \mathrm{Ca}$, and $\mathrm{Fe}$ and depleted in $\mathrm{Si}$ and $\mathrm{K}$ relative to the bulk glass. The glass was well reacted, but not very well mixed.

\section{USBM Glass Product}

USBM designated its initial melter run WHCl. Following the observations of WHC1, USBM conducted two additional melter runs designated WHC2 and WHC3 which used excess dried feed left over from run WHCl and involved a lesser degree of characterization. The purpose of runs WHC2 and WHC3 was to test melter modifications made in an attempt to reduce volatility of feed components.

The USBM glass was highly reduced with essentially all the $\mathrm{Fe}$ in the $\mathrm{Fe}^{+2}$ ferrous state, which is most likely a result of reduction by the carbon electrodes in this melter. PCT Na releases measured on the $\mathrm{WHCl}$ run glass samples were all below those measured for the target composition, which is consistent with the lower $\mathrm{Na}_{2} \mathrm{O}$ and higher $\mathrm{Al}_{2} \mathrm{O}_{3}$ and $\mathrm{SiO}_{2}$ contents relative to the target composition. The WHCl run glass was tapped from the melter at approximately $1500^{\circ} \mathrm{C}$ versus a $1296^{\circ} \mathrm{C}$ melting temperature at $10 \mathrm{~Pa}-\mathrm{s}$ (100 poise) viscosity measured for the target glass composition.

The WHC 1 run samples contained $<1$ vol\% inclusions, most of which were optically opaque. These opaque inclusions were generally Mo metal or Mo sulfide with particle sizes $<\mu \mathrm{m}$. No evidence of devitrification was observed. The bulk glass was black. Thin fractured chips were translucent with a dark smokey color when observed with back lighting. Numerous faint to heavy cords were present. The cords were enriched in $\mathrm{K}, \mathrm{Na}, \mathrm{Mo}$, and $\mathrm{Fe}$ and depleted in $\mathrm{Si}, \mathrm{Ca}, \mathrm{Al}$, and Ti relative to the average composition. This glass can be characterized as well reacted, but poorly mixed, cordy, and very reduced.

\section{Vectra Glass Product}

The $15.4 \% \mathrm{Na}_{2} \mathrm{O}$ product glass sample values indicate almost one-fourth of the $20 \%$ target $\mathrm{Na}$ is not in the glass. Mass balance data suggest that approximately one-half of the missing $\mathrm{Na}_{2} \mathrm{O}$ was due to volatility losses during melting. The remainder relates to errors in the $\mathrm{Na}$ content of the melter feed.

The Vectra meit was very reducing as indicated by essentially all the $\mathrm{Fe}$ in the $\mathrm{Fe}^{+2}$ ferrous state. Redox ratios $\left(\mathrm{Fe}^{+2} / \mathrm{Fe}\right)>1.00$ are due to analytical uncertainties. The very reduced state of the glass likely indicates excessive additions of sucrose reductant. Durability of product glass samples was better than the target glass composition value, which is consistent with the lower $\mathrm{Na}_{2} \mathrm{O}$ content and higher melting temperature for actual product glass composition. Melting temperatures during the slurry feed and calcined feed test 
segments when these samples were taken were in the 1400 to $1450^{\circ} \mathrm{C}$ range versus a $1224^{\circ} \mathrm{C}$ melting temperature measured for the target glass composition at $10 \mathrm{~Pa}^{-}$(100 poise) viscosity.

Some of the Vectra glass samples exhibited abundant cords, but in other samples cords were absent. Occasional bubbles were present and inclusions were $<1$ vol\%. Inclusions were primarily Mo metal or Mo sulfide (Mo and S characteristic $X$-ray lines overlap) which is consistent with the reduced state of the melt and the amount of molybdenum electrode wear observed. No evidence of devitrification was observed and microprobe line scans up to $2 \mathrm{~mm}$ indicated no compositional fluctuations. The glasses appeared to be well mixed and reacted, but very reduced. Glass samples were clear and dark green.

\section{E. Duratek Glass Product}

In general, analyses of the Duratek glass samples agreed very well with their target glass composition.

The maximum $\mathrm{Fe}^{2 / 2} / \mathrm{Fe}$ redox ratio was 0.0015 with most measurements reported as $<0.0004$. The Duratek glass samples, along with those from the WSTC test, were the most oxidized glasses in terms of $\mathrm{Fe}^{+2} / \mathrm{Fe}$ ratio produced during the Phase 1 melter tests. Although urea reductant additive was included for $\mathrm{NO}_{3}^{-} \mathrm{NO}_{2}^{-}$reduction, the use of air bubbling from the bottom of the melter apparently prevented substantial reduction of the glass. PCT Na releases were somewhat lower than measured on the target glass composition.

The Duratek glass samples exhibited faint cords and no devitrification. Inclusions ranged up to $2 \mathrm{vol} \%$ and were primarily unreacted zircon grains that had Na-rich reaction rims. Zircon was used as part of the glass-former additive mixture and was apparently only partly reacted and did not completely dissolve in the melt. There were also trace amounts of aluminous stones and unmelted quartz grains as inclusions. A high level of small bubbles was also present in most glass samples. The glass appeared to be well mixed, but grains of the more refractory glass-former additives were not completely reacted.

\section{F. Envitco Glass Product}

The $17.4 \% \mathrm{Na}$ content in the glass falls short of the $20 \mathrm{wt} \%$ target due to deficiencies in the feed Na content. The redox data showed that about $60 \%$ of the Fe was reduced from $\mathrm{Fe}^{+3}$ to $\mathrm{Fe}^{+2}$ indicating that the $100 \%$ stoichiometric carbon addition (relative to $\mathrm{NO}_{3}^{-} / \mathrm{NO}_{2}^{-}$recuction) moderately reduced the glass. The moderately reduced glass appeared to be quite compatible with the molybdenum electrodes which exhibited very little wear during Phase 1 melter testing.
The measured glass PCT Na release values ranging from 0.01 to $0.028 \mathrm{~g} / \mathrm{m}^{2} /$ day were lower than the $0.046 \mathrm{~g}^{2} /$ day value measured for target glass composition, which is consistent with the lower $17.4 \% \mathrm{Na}_{2} \mathrm{O}$ content of the product glass samples, and the higher 1400 to $1450^{\circ} \mathrm{C}$ temperatures at which this glass was melted in the melter test, compared to the $1325^{\circ} \mathrm{C}$ melting temperature (at 100 poise viscosity) measured for the $20 \% \mathrm{Na}_{3} \mathrm{O}$ target glass.

Inclusions were not found in the Envitco glass and there was no evidence of devitrification. Glass samples were clear and ranged from light green to green to amber. Some faint cords were clear in plane-polarized light but revealed anisotropy under crossed polarizers suggesting internal stress lines. A few small bubbles were observed, but in general, the glass appeared to be well reacted and uniform. Continuous microprobe scans for several diagnostic elements over a distance of up to $1.5 \mathrm{~mm}$ did not reveal any discontinuities indicating a chemicaliy homogeneous product.

\section{SELECTIVE AND NON-SELECTIVE LOSSES}

This section discusses the selective and non-selective losses, assumed to be volatility and entrainment, respectiveiy, from the melter systems. Losses are determined from offgas aerosol samples and by examining feed and glass compositions as explained below.

\section{A. Methodology}

Use of the tie component or intemal standard analyses supplements direct measurement of offgas emissions and provides improved data in some situations. The tie component calculation allows calculation of the volatility of components from the feed and glass compositions of a melter that is compositionally at steady state. First, a component that is known to have little or no volatility at the melter conditions is selected as an internal standard. In addition to being nonvolatile, the component should be present in sufficient quantity to allow accurate analytical determination and should not be subject to contamination from non-feed sources such as refractory or electrode corrosion or other sources. Typical tie components selected for these tests include $\mathrm{SiO}_{2}, \mathrm{Al}_{2} \mathrm{O}_{3}, \mathrm{Fe}_{2} \mathrm{O}_{3}$, $\mathrm{CaO}$, and $\mathrm{SrO}$ with the selection depending on the details of the melter operation. The concentration of the volatile component is compared to the tie component in the feed and glass. The equation is as follows: 
fraction of component volatilized $=\frac{v_{f} \frac{t_{g}}{t_{f}}-v_{g}}{v_{f} \frac{t_{g}}{t_{f}}}$

where:

$v_{f}=$ mass fraction volatile component in feed

$v_{g}=$ mass fraction volatile component in glass

$t_{f}=$ mass fraction tie component in feed

$t_{g}=$ mass fraction tie component in glass

The advantages of the tie component method are that it relies only on compositional analysis and does not require accurate measurement of masses of feed and glass materials. It is only the concentration ratios of volatile components to the tie components that are important. The accuracy of the results is not affected by loss of other volatile components such as water, nitrates, or carbonates from the feed. In addition, nonselective loss mechanisms such as accumulation, feed spillage, and gross entrainment of the feed do not affect results. Although the method does not detect non-selective entrainment of feed to the offgas, the validity of the volatility result is not adversely affected. The method works best when the extent of volatility is relatively large such that the change in concentration is much larger than the analytical uncertainty. When the volatility is very small, analytical errors in the feed and glass materials analyses result in large uncertainties. If the melter is not at steady state with respect to a given component due to changes in feed composition, errors can be introduced. Also, if there is a source of a component other than from the feed (such as refractory or electrode corrosion) the results will reflect this as a smaller than expected or even a negative measurement of volatility.

Entrainment is determined based on the quantity of nonvolatile oxides collected in aerosol samples. The total loss from the melter is determined from estimates of the entrainment (nori-selective loss) and volatility (selective loss). The conceptual model of the process is that the gross entrainment occurs first and equally entrains all components the volatility then occurs from the remainder. The percent volatilized in this conceptual model can be determined based only on glass and feed composition with no knowledge of the degree of gross entrainment. The equation used to recombine the volatility and entrainment value to determine the fraction of each element partitioning to the offgas is as follows.
$L_{T}=L_{e}+L_{v}\left(1-\frac{L_{e}}{100}\right)$

where:

$L_{\tau}=$ percent total loss of component to offgas

$L_{v}=$ percent volatile loss of component

$L=$ percent non-selective entrainment of feed

\section{B. Estimates of Gross Entrainment of Feed}

Entrainment refers to material that is physically captured by the offgas flow. Entrainment may result from dusting of a dry feed, boiling of wet feed in a cold cap, or a failure of feed to completely segregate from gases for melters such as those as B\&W or WSTC. It is assumed that loss by entrainment is nonselective and entrains all components equally. Selective entrainment is possible, and if present it is included in this evaluation as volatility. Table 2 provides estimates of the percent entrainment for each vendor test. These values are based primarily on aerosol sampling using EPA Methods 5 or 29 but also consider measurements of material that collected in downstream offgas equipment. In general, the Joule-heated melters show significantly less entrainment than other types of melters.

Table 2. Percent Gross Entrainment Estimates."

\begin{tabular}{|l|l|}
\hline \multicolumn{1}{|c|}{ Vendor } & \multicolumn{1}{c|}{$\%$ Gross entrainment } \\
\hline B\&W & 8.7 \\
\hline WSTC & 2.7 \\
\hline USBM WHC-1 & 1.2 \\
\hline Duratek & 0.6 \\
\hline Vectra $^{b}$ & 0.6 \\
\hline Envitco & 0.05 \\
\hline
\end{tabular}

No data available for USBM WHC2 and WHC3 tests. Results from WHCl 1 are assumed to apply.

'Slurry feeding. Entrainment was $0.07 \%$ for calcined feed and $0.4 \%$ for simulated calcine.

\section{Estimates of Volatile Feed Losses}

Selective loss of components through volatilization is a somewhat greater concern than gross entrainment for the LLW vitrification systems. Estimates of volatile losses and total losses including entrainment are shown in Table 3. 
Table 3. Loss of Selected Feed Components to Offgas During Testing of Various Melter Systems. (Percent Volatile Loss)/(Percent Total Loss).

\begin{tabular}{|c|c|c|c|c|c|c|c|}
\hline Oxide & $B \& W$ & WSTC & USBM WHC 1 & USBM WHC 3 & Vectra & Duratek & Envitco \\
\hline $\mathrm{B}_{2} \mathrm{O}_{3}$ & $67 / 70$ & $22 / 24$ & $51 / 52$ & $18 / 19$ & $14,\left(6.8^{\mathrm{ab} b}\right) / 15$ & $\sim 0^{4} / 0.6$ & $0.14 \% / 0.2$ \\
\hline $\mathrm{Cl}$ & $87 / 88$ & $88 / 88$ & $82 / 82$ & $97 / 97$ & $64 / 64$ & $47.8 / 48$ & 1 to $13^{2} / 1$ to 13 \\
\hline $\mathrm{Cs}_{2} \mathrm{O}$ & $83 / 85$ & 84 & $63 / 63$ & $39 / 40$ & $41 / 41$ & $13.2 / 14$ & $0.6^{2} / 0.6$ \\
\hline $\mathrm{F}^{\mathrm{c}}$ & $\sim 92 / 93$ & $\sim 91 / 91$ & $\sim 91 / 91$ & $\sim 99.7 / 99.7$ & $\sim 15^{2} / 16$ & $\sim 53 / 53$ & $\sim 0.85 \% 0.90$ \\
\hline I & $94 / 95$ & $>98 / 98$ & $95 / 95$ & N/A & $83 / 83$ & $82 / 82$ & $10 / 10$ \\
\hline $\mathrm{K}_{2} \mathrm{O}$ & $51 / 55$ & $48 / 49$ & $35 / 36$ & $25 / 26$ & $15,\left(8.5^{\mathrm{a}, \mathrm{b}}\right) / 16$ & $0 \%$ & $0 \% / 0.05$ \\
\hline $\mathrm{LiO}_{2}$ & N/A & $2.8 / 5.4$ & N/A & N/A & N/A & N/A & N/A \\
\hline $\mathrm{MoO}_{3}$ & $60 / 64$ & $24 / 26$ & $47 / 48$ & $45 / 46$ & SE & $0.2 \%$ & $0 \% 0.05$ \\
\hline $\mathrm{Na}_{2} \mathrm{O}$ & $35 / 41$ & $15 / 17$ & $21 / 22$ & $6.5 / 7.6$ & $13,\left(3.6^{a, b}\right) / 13.5$ & $\sim 0 \% .6$ & $0 \% 10.05$ \\
\hline $\mathbf{P}$ & $\sim 41 / 46$ & $43 / 45$ & $41 / 42$ & $54 / 55$ & $1.1 \% 1.7$ & $N / A^{\circ}$ & $0 \% .05$ \\
\hline $\mathrm{s}$ & $>51 / 55$. & $34 / 36$ & $88 / 88$ & 94/94 & $85,\left(56^{2, b}\right) / 85$ & N/A $A^{\circ}$ & $53 / 53$ \\
\hline
\end{tabular}

- Estimates based on aerosol sampling data. Other data are from tie calculation using glass and feed composition data.

'Because of uncertainty, both tie component and aerosol measurement volatility results are presented for some analytes. There is reason to suspect aerosol measurements may under-represent the volatility. Tie component values are based on target feed compositions due to inadequate characterization of melter feed.

c Analysis systematically under-reported fuoride content in feed. Feed targets were used to determine all fluoride volatility results. Uncertainty may also exist with respect to fluoride glass and Method 5 analyses. Therefore, all fluoride results are considered questionable.

N/A $=$ Not available. Data are unavailable on which to base a defensible estimate.

$\mathrm{SE}=$ Source error. Because of a source from erosion of molybdenum electrodes, no estimate is possible. 
Most volatile losses are determined by tie component calculations. Values derived from offgas sampling are identified in the table by footnotes.

1. Alkali Metals (Li, Na, K, Cs). The volatile loss of $\mathrm{Na}$ was severe $(35 \%)$ for the cyclone combustion melter (B\&W) and was $>3 \%$ for other melter systems except the Duratek and Envitco meiters. Duratek and Envitco showed very low Na volatile loss. The volatile loss of $\mathrm{K}$ was greater than for Na but showed a similar trend with the melter system. The single data point for volatile loss of $\mathrm{Li}$ (WSTC) indicates a volatile loss substantially lower than for $\mathrm{Na}$ or $\mathrm{K}$, likely because the $\mathrm{Li}$ was contained in the pre-melted glass frit. Cesium losses exceeded losses of other alkali metals in all cases. Even Duratek and Envitco, which showed very low $\mathrm{Na}$ losses, measured a $13 \%$ and $0.6 \%$ volatile loss of $\mathrm{Cs}$, respectively.

After USBM WHC1, modifications made to the USBM melter included the installation of larger electrodes to reduce the power density on the electrodes to one-fourth of the previous value. This reduced the Na volatile loss from $21 \%$ to $6.5 \%$. Lesser beneficial effects were observed for $\mathrm{K}$ and $\mathrm{Cs}$ as well.

2. Halogens (Cl, F, I). Chloride losses from the melter systems were very significant. With the exception of Envitco, melter systems lost $47 \%$ to $97 \%$ of the feed $\mathrm{Cl}$ by volatility. The Envitco melter experienced much lower losses. Because of analytical uncertainty, the Envitco $\mathrm{Cl}$ loss can only be narrowed down to the range of $1 \%$ to $13 \%$.

Fluoride volatile losses presented in Table 3 are shown as approximate values only. Analysis of control samples demonstrated that the analysis could substantially under-report $F$ in the feed. Because of this, $F$ target concentration values were used in all volatility calculations. There is a possibility that analytical under-reporting for $\mathrm{F}$ may have also occurred in glass and/or aerosol samples. Analysis results for F on Envitco (low volatile loss system) glass were reasonably close to the expected $\mathrm{F}$ content. If under-reporting is occurring in glass or aerosol samples, this would cause the $\mathrm{F}$ volatility estimates for B\&W, WSTC, USBM WHCl and WHC3, and Duratek to be too high and estimates for Vectra and Envitco to be too low. Generally, $\mathrm{F}$ losses showed similar trends to $\mathrm{Cl}$ losses.

Iodine volatility was determined based on neutron activation analysis of feed and glass samples. The iodine volatility was severe ( $>80 \%$ loss) for all melter systems except the Envitco melter which only lost about $10 \%$ of the feed I.

Surprisingly, the changes made to the melter for USBM WHC3, which resulted in reduced losses of alkali metals, resulted in increases in halogen losses. Chloride loss increased from $82 \%$ to $97 \%$ and $\mathrm{F}$ loss increased from $91 \%$ to $99.7 \%$. The reason for this is unknown.

3. Boron. Boron losses were very significant for many of the systems but were relatively minor for Duratek and Envitco. The modifications to the USBM melter between runs WHCl and WHC3 (larger electrodes to reduce the power density on the electrodes to one-fourth of the previous value) reduced the $\mathrm{B}$ volatile loss from $51 \%$ to $18 \%$.

4. Molybdenum. Molybdenum losses were significant for all the non-Joule heated melters. The loss from the Vectra melter cannot be determined because of the contamination from electrode erosion. Losses from Duratek and Envitco were shown to be small based on offgas samples. Tie calculations are qualitative at very low loss values but do confirm that the Mo losses from Duratek and Envitco are much lower than from B\&W, WSTC, or USBM.

5. Phosphorous. A significant fraction of the $P$ was lost to the offgas in several of the melter tests. However, significant analytical intereferences were encountered in the data in several cases.

In the $\mathrm{B} \& \mathrm{~W}$ test, analyses indicated $\mathrm{P}$ in the feed was consistently below target values. It was decided that target values were more likely correct than the analytical values, and the target values were used in calculating results presented in Table 3. Also, a source of $\mathrm{P}$ from refractory corrosion was present. The result presented is the maximum loss result based on feed target and glass analysis results.

In the Vectra test, the only feed sample analyzed indicated an excess of $P$ in the feed. Glass analyses also indicated an excess over the feed target values. Based on the apparent low loss and uncertainty in the feed for Vectra, the $\mathrm{P}_{2} \mathrm{O}_{5}$ volatility was determined from aerosol samples. The aerosol-based result is less sensitive to the feed concentration uncertainty.

In the Duratek test, the glass concentration of $\mathrm{P}_{2} \mathrm{O}_{5}$ was not at steady state and was dropping over time. Tie component calculations indicate a greater amount of $\mathrm{P}$ in the glass than the feed. There are no Method 5 data on which to base an aiternate estimate. Thus, while the volatility does not appear to be severe because the glass concentration remains above the feed concentration over the run, no specific estimate is available.

6. Sulfur. Volatile loss of $\mathrm{S}$ was significant for all melter tests. Envitco, which otherwise had low volatile losses, lost $53 \%$ of feed sulfur. In the case of $\mathrm{B} \& \mathrm{~W}$, all measurements of $\mathrm{SO}_{3}$ in the glass were below detection limits and the value of $51 \%$ represents the minimum $\mathrm{SO}_{3}$ volatile loss. Better detection limits were obtained during analysis of glass samples from subsequent melter tests. 
No result was presented for Duratek volatile loss of $\mathrm{SO}_{3}$ due to multiple uncertainties and conflicting data among feed target values, feed analysis values, and $\mathrm{SO}_{2}$ offgas data.

\section{NO $\mathrm{NMISSIONS}_{\mathrm{x}}$}

$\mathrm{NO}_{\mathrm{x}}$ emissions are of particular interest due to the high nitrate/nitrite content of the DSSF waste. At $10 \mathrm{M} \mathrm{Na}$, the DSSF waste is $3.2 \mathrm{M}$ in $\mathrm{NO}_{3}^{-}$and $1.7 \mathrm{M}$ in $\mathrm{NO}_{2}^{-}$. The generation of $\mathrm{NO}_{x}$ was examined for each of the vendor technologies. An No $\mathrm{N}_{\mathrm{x}}$ yield was calculated by comparing the molar flow of nitrate and nitrite in the melter feed to the molar emission rate of $\mathrm{NO}_{x}$ in the offgas. No attempt was made to separate $\mathrm{NO}_{x}$ between thermal and feed $\mathrm{N}$ sources. Results are calculated for the actual feed entering the melter and also for the feed preparation and melter considered as an integrated system where appropriate. $\mathrm{NO}_{x}$ yields based on feeds entering the melter are presented in Table 4.

Table 4. NO ${ }_{x}$ Generation for Various Melter Systems.

\begin{tabular}{|c|c|}
\hline Vendor & $\begin{array}{l}\mathrm{NO}_{x} \text { yield to offgas as mol\% of nitrate } \\
\text { and nitrite in melter feed }\end{array}$ \\
\hline$B \& W$ & 68 \\
\hline WSTC & $\mathrm{CD}^{2}$ \\
\hline USBM WHCI & $0.03^{b}$ \\
\hline USBM WHC3 & No data \\
\hline Vectra & 2.6 \\
\hline Duratek & 13 \\
\hline Envitco & $-33^{b}$ \\
\hline
\end{tabular}

"Conflicting data; see text below.

'Melter feed contains reduced levels of nitrite/nitrate due to the feed preparation process.

The high yield experienced in the $B \& W$ test may be due to the high offgas flow rate and thermal $\mathrm{NO}_{x}$ sources.

The WSTC test produced conflicting data. Online analyzers indicated $8 \%$ yield while bomb samples indicated $62 \%$ yield. Irregularities in the Ar analysis results from bomb samples raise doubts about the validity of the samples. However, there is a potential for condensation and scrubbing in the sample lines before measurement which could cause online monitors to under-report $\mathrm{NO}_{x}$ concentrations.

USBM added powdered sugar and activated carbon to the feed and dried and reacted the feed which destroyed $78 \%$ of the nitrate/nitrite before feeding the melter. The melter destroyed the residual nitrate/nitrite while releasing only very small amounts of $\mathrm{NO}_{\mathrm{x}}$. Laboratory data indicate the $\mathrm{N}$ evolved during the feed drying/reacting process is removed in the following forms: $9.6 \%$ as $\mathrm{NO}_{x}, 15.6 \%$ as $\mathrm{N}_{2} \mathrm{O}, 9.8 \%$ as $\mathrm{NH}_{3}$, and $65 \%$ as $\mathrm{N}_{2}$. Extrapolating these results to the pilot-scale system and considering the melter and feed preparation process as an integrated system, the overall $\mathrm{NO}_{\mathrm{x}}$ yield is $7.4 \%$. Additional data were not collected during the WHC3 test.

Vectra directly fed slurry feed that contained sucrose as a reductant additive. This approach resulted in the lowest $\mathrm{NO}_{\mathrm{x}}$ yield for an integrated system although the melter $\mathrm{NO}_{x}$ yield was higher than for the USBM melter.

Duratek added urea to its slurry feed as a reductant. The $13 \% \mathrm{NO}_{\mathrm{x}}$ yield shown in Table 4 is based only on feed nitrate/nitrite and neglects $\mathrm{N}$ associated with the urea.

Envitco added activated carbon to the feed and attempted to obtain nitrate/nitrite destruction during a spray-drying process. The reaction during spray drying only eliminated approximately $25 \%$ of the feed nitrate/nitrite. However, no offgas data were obtained from the spray-drying process. Later reactions in the melter resulted in relatively high $\mathrm{NO}_{\mathbf{x}}$ emissions.

\section{SUMMARY}

Commercially available vitrification technologies were tested as candidate technologies for vitrification of the LLW stream to be derived from retrieval and pretreatment of Hanford Site tank waste. All the vendor glass samples from Phase 1 meiter testing were sufficiently durable to meet the $<1 \mathrm{~g} / \mathrm{m}^{2} /$ day PCT Na release requirement for Phase 1 glass formulations. Product glass samples varied in homogeneity with some containing inclusions of unmelted batch components or refractory. The cyclone combustion melter product glass was the least homogeneous.

Loss of waste oxides by volatility and entrainment are important considerations for vitrification of the high-Na content Hanford Site LLW. Volatility and entrainment will impact offgas treatment design and operation, secondary waste quantity and composition, and if severe, excessive volatility will affect the product glass composition and properties. Lowest feed component volatility and offgas entrainment losses were observed in the Joule-heated meiter tests, with the lowest losses observed in the Envitco test using dried feed and full batch coverage in the melter. The greatest volatility and entrainment losses occurred with the B\&W cyclone combustion melter. Relatively high losses also occurred in the plasma torch-fired melter (WSTC) and the initial carbon electrode melter (USBM) tèsts. The USBM subsequently demonstrated somewhat lower losses of alkali metals and $B$ after making equipment modifications.

Various reductant feed additives including sugar, 
powdered carbon, and urea were tested for reducing $\mathrm{NO}_{\mathrm{x}}$ emissions by destruction of feed nitrate and nitrite. Sugar addition to slurry feed as demonstrated by Vectra, and sugar plus carbon reductant in prereacted dried feeds as demonstrated by USBM, appeared to be the most effective feed additives for reduction of $\mathrm{NO}_{\mathrm{x}}$ emissions. $\mathrm{NO}_{\mathrm{x}}$ emissions from the carbon electrode melter were very low based on the melter feed $\mathrm{N}$ content.

\section{REFERENCES}

1. Washington State Department of Ecology, U.S. Environmental Protection Agency, and U.S. Department of Energy, Hanford Federal Facility Agreement and Consent Order, as amended, Olympia, Washington (1994).

2. Wilson, C. N., Melter System Technology Testing for Vitrification of Hanford Site Low-Level Tank Waste, paper at this meeting.

3. Wilson, C. N., editor, Low-Level Waste Vitrification Phase 1 Melter Vendor Demonstration Testing Summary Report, WHC-SD-WM-ER-498, Rev. 0, Westinghouse Hanford Company, Richland, Washington (1996).

4. Whyatt, G. A., M. R. Powell, G. E. Stegen, C. N. Wilson, Low-Level Waste Phase I Melter Testing Offgas and Mass Balance Evaluation, WHC-SD-WM-ER-517, Rev. 0 , Westinghouse Hanford Company, Richland, Washington (1996).

5. Wilson, C. N., Statement of Work for Evaluation of Melter System Technologies for Vitrification of HighSodium Content Low-Level Radioactive Wastes, WHC-SD-WM-RD-044, Rev. 0, Westinghouse Hanford Company, Richland, Washington (1994).

6. Mast, E. S., Low-Level Waste Vitrification Phase I Vendor Testing Sample Analyses Data, WHC-SD-WM-DB-131, Rev. 0, Westinghouse Hanford Company, Richland, Washington (1995).

7. Higley, B. A., Glass Melter System Technologies for Vitrification of High-Sodium Content Low-Level Radioactive Liquid Wastes-Phase 1 SBS Demonstration with Simulated Low-Level Waste-Final Test Report, WHC-SD-WM-VI-024, Rev. 0, Westinghouse Hanford Company, Richland, Washington (1995).
8. Hendrickson, D. W., Evaluation of Plasma Melter Technology for Vitrification of High-Sodium Content Low-Level Radioactive Liquid Wastes - Demonstration Test Number 4 Final Report, WHC-SD-WM-VI-016, Rev. 0, Westinghouse Hanford Company, Richland, Washington (1995).

9. Eaton, W. C., U.S. Bureau of Mines, Phase I Hanford Low-Level Waste Melter Tests: Final Report, WHC-SD-WM-VI-030, Rev, 0, Westinghouse Hanford Company, Richland, Washington (1995).

10. Stegen, G. E., Vectra GSI Inc., Low-Level Waste Melter Testing Phase 1 Test Report, WHC-SD-WM-VI-031, Rev. 0, Westinghouse Hanford Company, Richland, Washington (1995).

11. Eaton, W. C., GTS Duratek, Phase I Hanford Low-Level Waste Melter Tests: Final Report, WHC-SD-WM-VI-027, Rev. 0, Westinghouse Hanford Company, Richland, Washington (1995).

12. Wilson, C. N., Envitco, Inc., Phase I Low-Level Waste Melter Demonstration Test Report, WHC-SD-WM-VI023, Rev. 0, Westinghouse Hanford Company, Richland, Washington (1996).

13. American Society for Testing and Materials, Standard Method for Determining Chemical Durability of Nuclear Waste Glasses: The Product Consistency Test (PCT), ASTM C 1285-94, Easton, Maryland (1994).

14. U.S. Department of Energy, Office of Civilian Radioactive Waste Management, Waste Acceptance System Requirements Document (WASRD), DOE/RW-0351P, Rev. 1, Washington D.C. (1994). 
E. J. Kosiansic

M. J. Kupfer

S. L. Lambert

E. S. Mast

R. J. Murkowski

S. R. Nelson

R. M. Orme

C. A. Petersen

E. H. Randklev

J. W. Shade (5)

J. X. Smith

G. E. Stegen (5)

J. A. Voogd

D. J. Washenfelder

G. F. Williamson

C. N. Wilson (5)

Central Files

Document Processing Center
H5-61

H5-27

H5-27

S3-90

H5-03

B4-55

H5-27

H5-27

H5-27

H5-27

S3-90

H5-27

H5-03

H5.61

HS-03

H5-27

A3-88

A3-94 


\section{DISTRIBUTION}

Number of copies

OFFSITE

2 Washington State Department

of Ecology

Nuclear Waste Program

P.O. Box 47600

Olympia, WA

J. Granthum (2)

\section{ONSITE}

7 U.S. Department of Energy.

Richland Operations Office

N. R. Brown

K6-51

S. T. Burnum

L. Erickson

R. A. Gilbert

K6-51

L. A. Huffinan

K6-51

P. E. LaMont

S7.53

G. H. Sanders

S7.53

I3 Pacific Northwest National Laboratory
X. Feng
P8-44
C. J. Freeman
P7-41
P. R. Hrma
P8-37
H. $\mathrm{Li}$
P8-44
J. M. Perez
P7-41
D. Vela
K6-51
J. H. Westsik
K9-80
K.D. Wiemers
K6-51
G. A. Whyatt (5)
P7-19

42 Westinghouse Hanford Company

M. J. Bowman

G1-25

K. C. Burgard

H5-03

R. B. Calmus

HS- 27

R. P. Colburn

H5-27

W. C. Eaton

H5-27

P. Felise

B4-55

J. S. Garfield

H5- 49

R. L. Gibby

H5-27

D. W. Hendrickson

L5-31

B. A. Higley

H5-27

J. O. Honeyman

G3-21

M. E. Johnson

G3-21 